\title{
PRESERVATION OF VITAMIN C, LYCOPENE AND CARBOHYDRATE CONTENT IN TOMATO DRIED IN A TUNNEL TYPE DRYER
}

\author{
Jasmina M. Zdravković ${ }^{* 1}$, Nenad V. Pavlović ${ }^{1}$, Nevenka M. Bošković Vragolović ${ }^{2}$, Đorđe Ž. \\ Moravčević ${ }^{3}$, Milan M. Šević ${ }^{1}$ \\ ${ }^{1}$ Institute for Vegetable Crops, Karađorđeva 71, Smederevska Palanka, Serbia \\ ${ }^{2}$ University of Belgrade, Faculty of Technology and Metallurgy, Karnegijeva 4, Belgrade, Serbia \\ ${ }^{3}$ University of Belgrade, Faculty of Agriculture, Nemanjina 6, 11080 Beograd-Zemun, Serbia
}

\author{
${ }^{*}$ Corresponding author: \\ Phone:+38126317170 \\ Fax: +38126317785 \\ E-mail address: jzdravkovic@institut-palanka.co.rs
}

\begin{abstract}
The aim of this study was to find an optimal way of tomato drying in a tunnel type dryer, in order to achieve the lowest possible losses in nutritive value of dried tomato products. Domestic variety of tomato (SP-109) was used in this research. Drying was performed in three ways, applying five temperature regimes, as follows: cocurrent system (variant 1 at $70-80{ }^{\circ} \mathrm{C}$; variant 2 at $90-75{ }^{\circ} \mathrm{C}$ ), countercurrent system (variant 1 at $55-65{ }^{\circ} \mathrm{C}$, variant 2 at $65-75{ }^{\circ} \mathrm{C}$ ) and combined system $\left(85-55{ }^{\circ} \mathrm{C}\right.$ and $55-65{ }^{\circ} \mathrm{C}$ ). In these systems, the kinetic of changes in nutritive value of tomato fruits was monitored by measuring the content of carbohydrates, lycopene and vitamin C. Different influences of temperature regimes on nutritive value of dried tomato were observed at the level of statistical difference (LSD $0.05 ; 0.01$ ) in the researched systems. Cocurrent system was statistically significant for differences in temperature modes (variant 1 and variant 2). Monitoring of the tomato drying kinetics showed that, in all variants, period of constant drying rate lasted about $3.5 \mathrm{~h}$ and that the total drying was the fastest in parallel cocurrent flow of non-saturated hot air and material. The content of total carbohydrates in tomato was dependent on the temperature regime of the tested drying systems. The carbohydrate content obtained in tomato samples dried at lower temperatures was higher compared to the values observed in the samples dried at higher drying temperatures. Significant losses of vitamin $\mathrm{C}$ were determined in all drying systems. The lycopene content under all experimental conditions generally showed a tendency to decrease slightly. Comparing its content in dry and fresh tomato fruits, the loss ranged from $4.94 \%$ to $19.98 \%$ but did not reach the significant level as the occurrence remained below $95 \%$ of cases.
\end{abstract}

Key words: concurrent flow, countercurrent flow, drying kinetics, lycopene, temperature, vitamin C

\section{INTRODUCTION}

Limited lifetime and senescence of tomato fruits is a main problem in tomato marketing. In order to prolong time of tomato consummation without significant loss of product quality technological processing is applied, drying among others. The demand for tomato products is constantly increasing in the world tomato market (Verlent et al., 2006).
The most common tomato drying system of a tunnel type are cocurrent and countercurrent hot air directing. Cocurrent system means forced movement of the heated agents in the direction of the movement of products, while in countercurrent system directions of hot agent and products are opposite. However, due to high moisture of its fruits with over $90 \%$ of water (Lavelli 
et al., 2013) tomato does not react well on high temperatures. The reason for this is good conduction of heat through the water, which affects the delicate nutritional matters in the product.

Drying is a process of transition of liquid to gas (Fellows, 2009). Moisture removal must be carried out by the procedure that is the least harmful to the quality of the product.

Drying as a method of processing keeps the desired product qualities for a longer period of time (Akanbi et al., 2006; Brooks et al., 2008). Tomato drying is most commonly carried out to the level of moisture of $25 \%$ (semi-dried) (Muratore et al., 2008 ), or to the absolute dried product (12-14\% of moisture) (Sacilik et al., 2006, 2007 ), depending on the type of product the dried tomato is being prepared for. In order to better preserve the physico-chemical traits as well as the nutritive quality of tomato during drying in a tunnel type dryer with conveyor belt, the most analysed traits are the lycopene level, dehydration index and total sugars (Mohseni and Ghavidel, 2011).

Lycopene is a carotenoid typical for tomato and experience of researchers about its lifetime after drying are different (Zanoni et al., 2000). Therefore, many studies were dedicated to the drying process and changes that occur as a result of the drying.

Most of the experimental results showed that lycopene was relatively thermo-stabile during processing, unlike vitamin $\mathrm{C}$ which is depredated during drying process. Toor and Savage (2006) found that the level of vitamin $C$ in fresh tomato fruits was decreased after drying from $284 \mathrm{mg} / 100 \mathrm{~g}$ to $223 \mathrm{mg} / 100 \mathrm{~g}$. There is a standpoint that dried tomato fruits have a lower level of lycopene.

Nguyen and Schwartz (1998), Lavelli et al. (2013) proved in their researches that the lycopene level in fresh samples was from $63 \mathrm{mg} / 100 \mathrm{~g}$, while in dried fruits it was 54 $\mathrm{mg} / 100 \mathrm{~g}$. A group of authors found that the total level of lycopene was increased by drying as well as total antioxidative activity (Giovanelli et al., 2002; Eltoum and Babiker, 2014). However, it would be interesting to point out that heat had positive impact on increasing the bioavailability of lycopene.

During technological processing of tomato (sauce, ketchup etc.) lycopene was not distroyed but increased (Stahl and Sies, 1992; Gärtner et al., 1997). Tomato and its products obtained with different technological processes are very important sources of carotenoid (lycopene) and vitamin C (Vinson et al., 1998; Khachik et al., 2006).

The aim of this study was to find an optimal way of tomato drying in a tunnel type of dryer by using different technological drying systems which would provide minimum losses of nutrients characteristic for fresh tomato.

\section{MATERIAL AND METHODS}

\section{Preparation of raw material}

Elongated tomato variety SP-109, selected at the Institute for Vegetable Crops has been used in this study. Tomato has been grown by applying standard technology in the experimental field of the Institute.

The tomato was sown in March in a green house for seedlings, and planted on May $10^{\text {th }}$ in the open field. Standard cultivation for this technology of tomato production was used (Zdravković et al. 2012).

The average mass of one fruit was 70-90 g. Fruits were washed with water and cut in half, and then the halves were laid on the shelf for drying. The capacity of one shelf was about $23 \mathrm{~kg}$ of fresh fruits. Used dryers were tunnel type (Progres, Čačak, Serbia) with capacity of up to $300 \mathrm{~kg}$ of fresh vegetables.

\section{Drying variants}

Tomato fruits were dried in a tunnel type dryer with warm air flow rate of $1.2 \mathrm{~m} / \mathrm{s}$, at different temperature regimes and different air movement relative to shelf with material (details shown in Table 1).

Dynamics in change of humidity in fruits was recorded every 30 minutes. The samples were dried until $12-14 \%$ of moisture was reached. 
Table 1.

Temperature regimes and drying duration

\begin{tabular}{lccc}
\hline Drying system & $\begin{array}{c}\text { Temperature } \\
\text { mode }\end{array}$ & $\begin{array}{c}\text { Drying duration } \\
\text { (h:min) }\end{array}$ & $\begin{array}{c}\text { Temperature } \\
\text { regimes } \\
\text { ( }{ }^{\circ} \mathbf{C} \text { ) }\end{array}$ \\
\hline $\begin{array}{l}\text { I parallel (concurrent) } \\
\text { direction }\end{array}$ & Variant 1 & $8: 30$ & $70-80^{\circ} \mathrm{C}$ \\
& Variant 2 & $8: 00$ & $90-75{ }^{\circ} \mathrm{C}$ \\
II countercurrent air & Variant 1 & $9: 30$ & \\
direction & Variant 2 & $9: 00$ & $55-65{ }^{\circ} \mathrm{C}$ \\
& & $9: 30$ & $65-75^{\circ} \mathrm{C}$ \\
III combination & & & $86-55^{\circ} \mathrm{C}$ \\
\hline
\end{tabular}

\section{Tomato moisture determination}

Free moisture contents in a sample $X$ was calculated as:

$\mathrm{X}=\left(\mathrm{W}-\mathrm{W}_{\mathrm{s}}\right) \mathrm{W}_{\mathrm{s}}$

where $W$ is total weight of the wet material

$W_{s}$ is the weight of the dry material.

\section{Index of dehydration}

Dehydration index is a measure of drying efficiency and represents a ratio of mass of fresh fruits before and mass after drying.

\section{Determination of vitamin C}

Sample preparation: By pressing tomato, $100 \mathrm{~cm}^{3}$ of pale tomato juice was obtained. The juice was homogenized and mixed with equal quantity $\left(100 \mathrm{~cm}^{3}\right)$ of mixture of $\mathrm{HPO}_{3}$ and glacial acetic acid $\mathrm{CH}_{3} \mathrm{COOH}$. Then, the mixture was filtrated through filter paper. First $5-10 \mathrm{~cm}^{3}$ of filtrate was thrown away, while from the rest, $10 \mathrm{~cm}^{3}$ of aliquot was taken for further study. Where it was necessary, the researched sample was diluted with boiled and cooled distilled water, so the aliquot portion contained about $2 \mathrm{mg}$ of vitamin $\mathrm{C}$.

Method for determining the vitamin $\mathrm{C}$ in the sample: In 3 Erlenmeyer dishes, 10 $\mathrm{cm}^{3}$ of filtrate sample (containing $5 \mathrm{~cm}^{3}$ of juice and $5 \mathrm{~cm}^{3} \mathrm{HPO}_{3}$ and glacial acetic acid $\mathrm{CH}_{3} \mathrm{COOH}$ ) was pipetted and titrated with Tillman's reagent (TR) to slightly pink colouring, stable for about five seconds. Along with the TR solution, a blind testing was titrated to the pink colour of the same intensity (Cvijović and Aćamović, 2005).

The content of vitamin $C$ was determined according to the following formula:

$\mathrm{C}$ vitamin $\left(\mathrm{mg} / \mathrm{cm}^{3}\right)=\frac{\left(\mathrm{V}-\mathrm{V}_{1}\right) \times \mathrm{T}}{\mathrm{g}} \times 100$

where

$\mathrm{V}-\mathrm{cm}^{3}$ of TR solution used in titration of trial

$\mathrm{V}_{1}-\mathrm{cm}^{3}$ of TR solution used for titration of blind testing

T- titer TR solution (mg $\mathrm{C}_{6} \mathrm{H}_{8} \mathrm{O}_{6} / 1 \mathrm{~cm}^{3}$ TR solution)

$\mathrm{g}$ - juice volume in $\mathrm{cm}^{3}$ in aliquot part of sample.

\section{Determination of lycopene}

$20 \mathrm{~g}$ of tomato was extracted in $100 \mathrm{~cm}^{3}$ of $96 \% \quad \mathrm{C}_{2} \mathrm{H}_{5} \mathrm{OH}$. After $24 \mathrm{~h}$ extractions (maceration), the sample was filtrated. The extract was evaporated till dry. Dry extract was dissolved in $10 \mathrm{~cm}^{3}$ of mixture of acetone-hexane (ratio 4: 6) and filtrated through Whatman No.4 filter paper. Obtained extract was diluted ten times and the absorption (A) at wavelengths of 453 , 505, 645 and $663 \mathrm{~nm}$ was measured. Spectrophotometric measurements of samples were performed by using a UVVIS spectrophotometer MA9523-SPEKOL 211 (Iskra, Horjul, Slovenia). The level of lycopene (mg lycopene/ $100 \mathrm{~mL}$ extract) was calculated by applying equation of Nagata and Yamashita (1992): 


$$
\text { Lycopene }(\mathrm{mg} / 100 \mathrm{~mL})=-0.0458 \times \mathrm{A}_{663}+0.204 \times \mathrm{A}_{645}+0.372 \times \mathrm{A}_{505}-0.0806 \times \mathrm{A}_{453}
$$

\section{Determination of carbohydrates}

This method determinates all carbohydrates with free semi-acetylene groups, that reproduce metal ions $\left(\mathrm{Cu}^{2+}\right.$ do $\mathrm{Cu}^{+}$ from reagents Bertrand I - $\mathrm{CuSO}_{4} \times 5 \mathrm{H}_{2} \mathrm{O}$ ). The quantity of copper (I)-oxide was equivalent to sugar quantity. Solution of Bertrand III $\left(\mathrm{Fe}_{2}\left(\mathrm{SO}_{4}\right)_{3}\right)$ copper (I)-oxide precipitate was dissolved, wherein the retransferred to the copper (II) and iron (III) is reduced to iron (II). In an acidic environment, iron (II) ions oxidized with an equivalent amount of $\mathrm{KMnO}_{4}$ in iron (III), and manganese (VII) turns to the manganese (II). According to the quantity of spent $\mathrm{KMnO}_{4}$ the appropriate amount of sugar was read from the table (Cvijović \& Aćamović, 2005).

\section{Data analysis}

Data of average losses of monitored bioactive compounds compared to fresh tomato were analysed with one-way analysis of variance (ANOVA) in three replications. The mean comparison was done with LSD (the lowest significant difference) test. The significance of difference was defined as $P$ $<0.05$ (Hoshmand, 1998). Software used to analyze data was standard Microsoft Office Excel 2007.

\section{RESULTS AND DISCUSSION}

\section{Drying kinetics}

The results shown in Fig. 1 were obtained in cocurrent flow of material and air for drying at different temperatures. The differrence in temperatures of air during drying was not significant in two experiments so the drying kinetic was practically identical. In both cases, period of constant rate of drying (period of removal of surface moisture) lasted about 3.5 hours. In the period between 3.5 and 6 hours, the material was dried in falling rate regime. The samples were dried for 6 hours.

In case of countercurrent drying of material (Figure 2), there was a slight difference in drying intensity at different air temperatures. It is interesting that during the period of constant drying rate at lower air temperature, the material dried faster. Af- ter the period of constant drying rate (for about $3.5 \mathrm{~h}$ ), in falling rate period, the drying kinetics with air of different temperature was practically the same and the material was completely dried after 7 hours of drying.

Figure 3 shows drying curves for all three drying ways investigated in this study. Besides cocurrent and countercurrent flow, the figure shows the results obtained by combined tomato drying.

Combined drying was performed as drying in cocurrent flow (first 3 hours) at 86-55 ${ }^{\circ} \mathrm{C}$ and then continued in countercurrent flow at temperature $55-65^{\circ} \mathrm{C}$.

Combined and cocurrent flow showed the same drying kinetics, while the countercurrent flow, according to drying curves, proved to be less effective.

The effectiveness of drying process in current flow was lower (required longer time) comparing to paralel system, which was indirectly related to energy consumption during drying.

However, from the aspect of nutrient preservation, this drying method exerted the best results regarding the preservation of carbohydrates and vitamin $\mathrm{C}$ at significant level (Tab 3), which can be attributed to lower temperature that do not cause nutrient degradation.

Drying process lasted for 6 hours. The values of dehydration index ranged from 18.08 for combined drying system to 23.02 for countercurrent (variant 2) system, at temperatures $65-75{ }^{\circ} \mathrm{C}$ (Tab 3). Our results harmonized with Owureku-Asare et al. (2014), where the dehydration coefficient was 19.4 at $55^{\circ} \mathrm{C}$.

The difference can refer to material, i.e. the variety used in drying process and it actually depends on dry matter content in fresh fruits before beginning of the drying process. Similar range of dehydration index was found by Mohseni \& Ghavidel (2011), when drying slices of tomato at temperatures of $65^{\circ} \mathrm{C}$, a dehydration index of 17.7 was determined. 


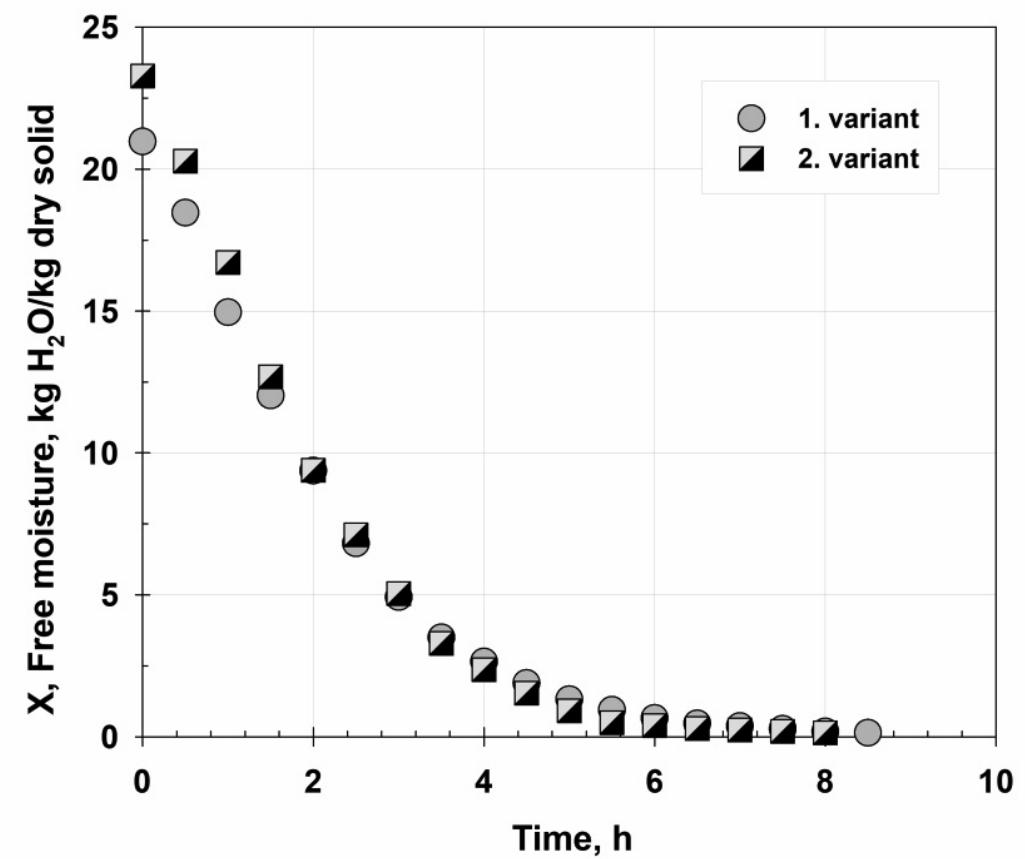

Figure 1. Variation of free moisture with drying time in tunnel dryer with cocurrent flow

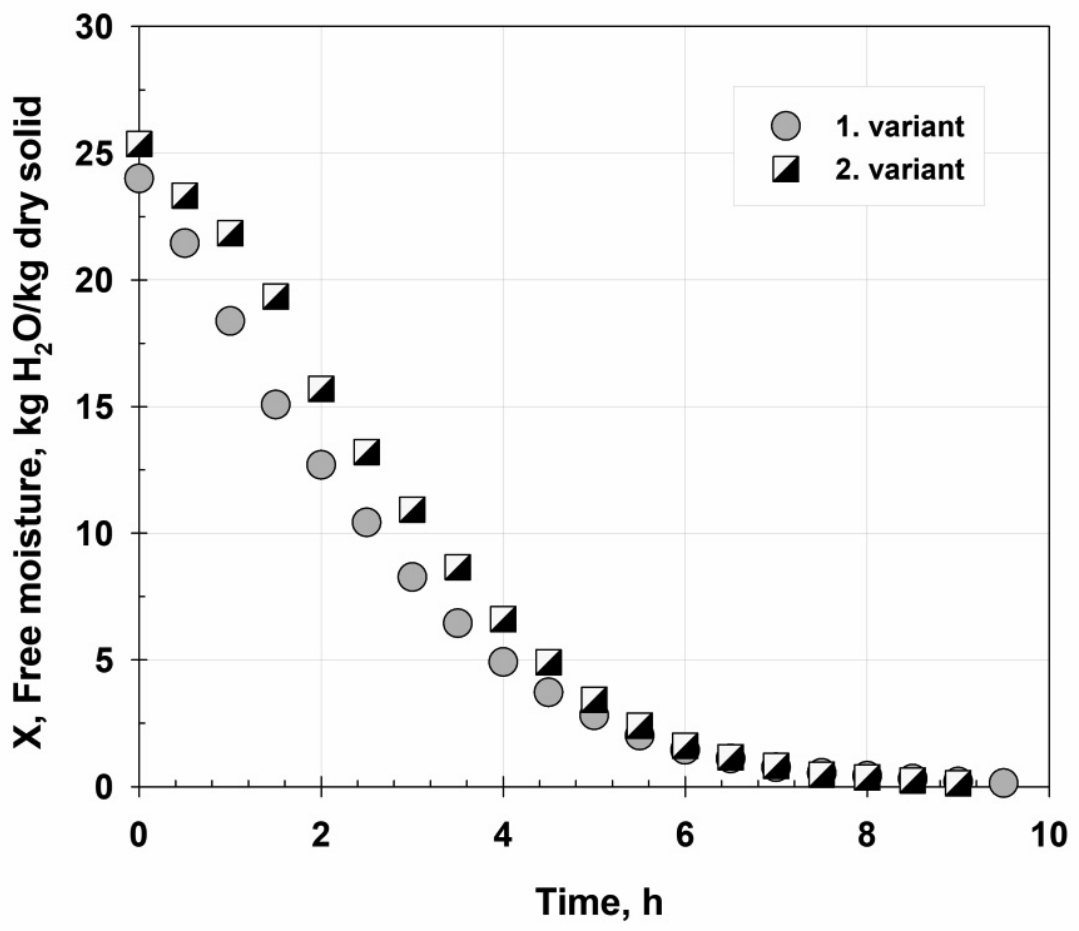

Figure 2. Variation of free moisture with drying time in tunnel dryer with countercurrent flow

\section{Changes in nutrients during drying}

There was a significant difference $(p<0.01)$ in vitamin $\mathrm{C}$ losses among all investigated drying systems, comparing to its total content in fresh tomato fruits.
The vitamin $C$ content was influenced by different methods of drying. The cocurrent system (variant 1 and 2) showed statistical difference (3.17 mg/100g for variant 1), whereas the losses were higher for variant $2(2.76 \mathrm{mg} / 100 \mathrm{~g})$. 


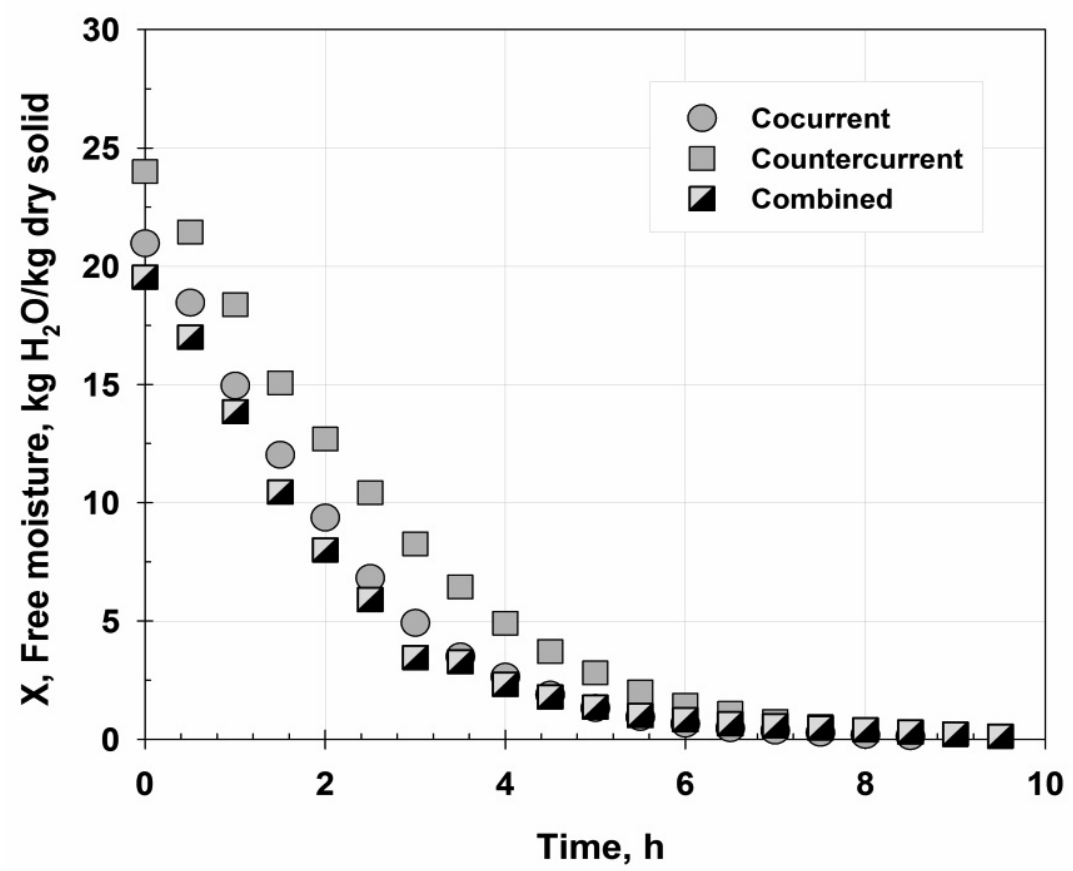

Figure 3. Variation of free moisture with drying time in tunnel dryer for different drying systems

Table 2.

The efficiency of tomato drying in different temperature regimes

\begin{tabular}{|c|c|c|c|c|c|}
\hline \multirow[t]{2}{*}{ Drying system } & \multirow[b]{2}{*}{$\begin{array}{c}\text { Drying } \\
\text { duration } \\
\text { (h:min) }\end{array}$} & \multirow{2}{*}{$\begin{array}{l}\text { Temp.re- } \\
\text { gimes } \\
\text { Start-end } \\
\left({ }^{\circ} \mathrm{C}\right)\end{array}$} & \multicolumn{2}{|c|}{ Tomato } & \multirow[b]{2}{*}{$\begin{array}{l}\text { Dehydration } \\
\text { index }\end{array}$} \\
\hline & & & $\begin{array}{c}\text { Fresh } \\
\text { weight } \\
\text { (kg) }\end{array}$ & $\begin{array}{c}\text { Dry } \\
\text { weight }(\mathbf{k g})\end{array}$ & \\
\hline \multicolumn{6}{|l|}{ I Cocurrent } \\
\hline Variant 1 & $8: 30$ & $70-80$ & 23.2 & 1.2 & 19.33 \\
\hline Variant 2 & 8:00 & $90-75$ & 23.5 & 1.1 & 21.36 \\
\hline \multicolumn{6}{|l|}{ II Countercurrent } \\
\hline Variant 1 & 9:30 & $55-65$ & 22.0 & 1.0 & 22.00 \\
\hline \multirow[b]{2}{*}{ III Combined } & 9:00 & $65-75$ & 23.2 & 1.0 & 23.20 \\
\hline & $9: 30$ & $\begin{array}{l}85-55 \\
55-65\end{array}$ & 23.5 & 1.3 & 18.08 \\
\hline
\end{tabular}

Table 3.

Changes in biochemical parameters in dried tomato fruits

\begin{tabular}{|c|c|c|c|c|c|c|}
\hline Material & $\begin{array}{l}\text { Temp. } \\
\text { regimes } \\
\text { Start-end } \\
\left({ }^{\circ} \mathrm{C}\right)\end{array}$ & $\begin{array}{c}\text { Carbo- } \\
\text { hydrates } \\
(\%)\end{array}$ & $\begin{array}{l}\text { Vitamin C } \\
(\mathrm{mg} / 100 \mathrm{~g})\end{array}$ & $\begin{array}{c}\text { Loss } \\
(\%)\end{array}$ & $\begin{array}{l}\text { Lycopene } \\
\text { (mg/100g) }\end{array}$ & $\begin{array}{c}\text { Loss } \\
(\%)\end{array}$ \\
\hline $\begin{array}{l}\text { Fresh tomato } \\
\text { I Cocurrent }\end{array}$ & & 3.89 & 6.804 & & 6.27 & \\
\hline $\begin{array}{l}\text { Variant } 1 \\
\text { Variant } 2\end{array}$ & $\begin{array}{l}70-80 \\
90-75\end{array}$ & $\begin{array}{l}5.06 \\
4.01\end{array}$ & $\begin{array}{c}3.17^{* *} \\
2.76\end{array}$ & $\begin{array}{l}53.41 \\
59.43\end{array}$ & $\begin{array}{l}5.88 \\
5.66\end{array}$ & $\begin{array}{l}6.22 \\
9.73\end{array}$ \\
\hline $\begin{array}{l}\text { II Countercurrent } \\
\text { Variant } 1 \\
\text { Variant } 2\end{array}$ & $\begin{array}{l}55-65 \\
65-75\end{array}$ & $\begin{array}{l}8.01^{* *} \\
6.22^{*}\end{array}$ & $\begin{array}{c}4.36^{\star *} \\
3.27\end{array}$ & $\begin{array}{l}48.79 \\
51.94\end{array}$ & $\begin{array}{l}6.02 \\
5.96\end{array}$ & $\begin{array}{l}3.99 \\
4.94\end{array}$ \\
\hline III Combined & $\begin{array}{l}86-55 \\
55-65\end{array}$ & 5.06 & 3.48 & 48.85 & 5.72 & 8.77 \\
\hline $\begin{array}{l}\text { LSD }_{0.05} \\
\text { LSD }_{0.01}\end{array}$ & & $\begin{array}{l}1.602 \\
2.427\end{array}$ & $\begin{array}{l}0.251 \\
0.380\end{array}$ & & $\begin{array}{l}0.932 \\
1.412\end{array}$ & \\
\hline
\end{tabular}


Similar scenario was observed for countercurrent drying system: variants 1 and 2 were statistically different. Lower loss was observed for tomato dried according to variant $1(48.79 \%)$ at lower temperatures. Combined way of drying proved that the loss of vitamin $\mathrm{C}$ was at the level of variant 2 , but it was significantly different from the cocurrent drying system, at the $95 \%$ confidence interval (Table 3).

For lycopene losses no statistical significance was observed indicating that lycopen was thermostable during the drying process. The obtained results were in accordance with researches of Zanoni et al. (2000), who found significant decrease in vitamin C comparing to fresh tomato, as well as lycopene but not at statistically significant level, during drying process in a shelf type dryers at temperatures $80{ }^{\circ} \mathrm{C}$ and $110^{\circ} \mathrm{C}$. During tomato drying at lower temperatures $\left(45,50\right.$ and $\left.60^{\circ} \mathrm{C}\right)$, the best drying conditions were at the temperature of $60{ }^{\circ} \mathrm{C}$ since it minimised degradation of lycopene $(2.9 \%)$, vitamin C (17.3\%) (Santos-Sánchez et al., 2012). Results of this research showed that the lowest loss of lycopene - $3.99 \%$ was achieved with counter-current air flow at temperatures $55-65{ }^{\circ} \mathrm{C}$ (variant 1). The calculated value of loss of lycopene during drying in this experiment, generally showed a slightly decreasing tendency (Tab. 3).

Our results were in accordance with Shi et al. (1999) who gave an explanation of the loss of the lycopene during air drying, which is based on the isomerization and oxidation (autoxidation) as two strong factors that influence the distribution of transand cisisomers and thereby its the biological potential.

Different ways of preparation for drying (Anguelova and Warthesen, 2000; Giovanelli and Paradiso, 2002; Goula and Adamopoulos, 2005), cutting into thin slices (Santos-Sánchez et al., 2012) or cutting into halves (Lavelli et al., 1999) can impact the speed and the quality of drying and the dried product. The way of preparation of tomato fruits for drying in our research was similar to that used in the work of Lavelli et al., 1999). They found that drying process resulted in a decrease of vitamin $\mathrm{C}$ level, while the level of lycopene remained unchanged, as it was confirmed in this research.

Following the results of Kerkhofs et al. (2005) after fruit drying at $42{ }^{\circ} \mathrm{C}$ (48 hours), three tomato varieties had significantly decreased vitamin $\mathrm{C}$ and total antioxidative activities and increased lycopene level. This study was conducted in order to identify tomato varieties with the best colour and the level of nutrients after drying. However, the general conclusion was that during drying process vitamin $\mathrm{C}$ was lost, while the lycopene was relatively well preserved, regardless to ways of raw material preparation or drying method (dryer or sun drying). Optimal drying conditions were $60{ }^{\circ} \mathrm{C}$, shorter time and thin slices of raw material (Correia et al., 2015).

The level of carbohydrates changed with the temperature increase for all investigated drying modes in tunnel type dryer. As compared to fresh fruits, the highest level of carbohydrates was found for countercurrent drying (both variants). Significantly higher level of carbohydrates was found for countercurrent mode which was depended on temperature. Since the temperature was lower in this mode, the difference could be caused by loss of carbohydrates at higher temperatures in parallel and combined drying system (Table 3 ). The loss of carbohydrates at higher temperatures was in accordance with Purkayastha et al. (2013). They found in their research that the carbohydrates level increased (2.1 times) in the process of drying at $50{ }^{\circ} \mathrm{C}$ and 1.3 times at $70{ }^{\circ} \mathrm{C}$. Dependence of carbohydrates in dried products and drying temperatures is in accordance with Zanoni et al. (2000). Sugar level could be lower at some drying modes comparing to fresh fruits (Bashir et al., 2014). General conclusion was that for drying process, optimal drying temperature should be defined in order to get high quality product and best cost-effectiveness of the production process.

Lately, the method of partial drying of tomato has been used more frequently. After this process the product was vacuumed and packed in polyethylene bags. By par- 
tial drying, tomato kept $25 \%$ of initial water content. During different length of treatment in air-dryers at temperatures 40,60 and $80{ }^{\circ} \mathrm{C}$ (Muratore et al., 2008) the level of vitamin $\mathrm{C}$, lycopene and beta-carotene was studied in order to estimate losses. Losses were lower in comparison to drying up to $12-14 \%$ of moisture. For some further researches, an option of partial fruit drying should be included.

\section{CONCLUSIONS}

Nutrient losses during drying were different for different variations of hot air flow. These losses were in function of temperature oscillations, so the vitamin $\mathrm{C}$ was best preserved at drying temperatures below $70^{\circ} \mathrm{C}$, whether the tomato was dried in parallel or in cocurrent hot air flow.

Carbohydrates were significantly best preserved in cocurrent hot air flow compared to parallel or combined hot air flow. According to this research, the preservation of carbohydrates was in function of temperature, so the recommendation is to dry tomato at low air temperatures for longer interval.

The content and change of lycopene as thermo-stabile bioactive compound did not show any differences after drying regardless to implemented drying systems or temperature regimes.

From the aspect of preservation of bioactive components in dried tomato product, the most acceptable was cocurrent hot air flow at temperatures below $70^{\circ} \mathrm{C}$.

\section{ACKNOWLEDGEMENTS}

This study was supported by the Serbian Ministry of Education, Science and Technological Development: Project No. TR31059 (Integrating Biotechnology Approach in Breeding Vegetable Crops for Sustainable Agricultural Systems).

\section{REFERENCES}

1. Akanbi, C.T., Adeyemi, R.S., Ojo, A. (2006). Drying characteristics and sorption isotherm of tomato slices. Journal of Food Engineering, 73,157-163.

2. Anguelova, T., Warthesen, J. (2000). Lycopene, stability in tomato powders. Journal of Food Science, 65, 67-70.
3. Bashir, N., Bhat, M.A., Dar, B.N., Shah, M.A. (2014). Effect of different drying methods on the quality of tomatoes. Advances in Food Research, 3, 65-69.

4. Brooks, M.S., Abou El-Hana, N.H., Ghaly, A E. (2008). Effects of tomato geometries and air temperature on the drying behaviour of plum tomato. The American Journal of Applied Sciences, 5, 1369-1375.

5. Correia, A. F.K. , Loro, A. C, Zanatta, S., Spoto, M.H.F., Vieira, T.M.F.S. (2015). Effect of temperature, time, and material thickness on the dehydration process of tomato international. Journal of Food Science, $7 \mathrm{p}$.

http://dx.doi.org/10.1155/2015/970724

6. Cvijović, M., Aćamović-Đoković, G., (2005). Praktikum iz biohemije, Agronomski fakultet, Čačak, Serbia, 175 pages. (in Serbian)

7. Eltoum, Y. A. I., Babiker E. E. (2014). Changes in antioxidant content, rehydration ratio and browning index during storage of edible surface coated and dehydrated tomato slices. Journal of Food Processing and Preservation, 38, 1135-1144.

8. Fellows, P. J. (2009). Food Processing Technology, $3^{\text {rd }}$ edition, Woodhead Publishing Limited and CRC Press, Boca Raton, FI, USA.

9. Gärtner, C., Stahl, W., Sies, H. (1997). Lycopene is more bioavailable from tomato paste than from fresh tomatoes. American Journal of Clinical Nutrition, 66, 116-122.

10. Giovanelli, G., Paradiso, A. (2002). Stability of dried and intermediate moisture tomato pulp during storage. Journal of Agricultural and Food Chemistry, 4, 7277-7281.

11. Giovanelli, G., Zanoni, B., Lavelli, V., Nani, R. (2002). Water sorption, drying and antioxidant properties of dried tomato products. Journal of Food Engineering, 52,135-141.

12. Goula, A.M., Adamopoulos, K.G. (2005). Stability of lycopene during spray drying of tomato pulp. LWT-Food Science and Technology, 38, 479-487.

13. Hoshmand, R. A. (1998). Statistical Methods for Environmental \& Agricultural Sciences, $2^{\text {nd }}$ edition, CRC Press, Boca Raton, New York, USA.

14. Kerkhofs, N.S., Lister, C. E., Savage, G.P. (2005). Change in colour and antioxidant content of tomato cultivars following forcedair drying. Plant Foods for Human Nutrition, 60, 117-121.

15. Khachik, F., Carvalho, L., Bernstein, P.S., Muir, G.J., Zhao, D.Y., Katz, N. B. (2006). Chemistry, distribution, and metabolism of tomato carotenoids and their impact on human health. Experimental Biology and Medicine, 227, 845851.

16. Lavelli, V., Hippeli, S., Peri, C., Elstner, E.F. (1999). Evaluation of radical scavenging activity of fresh and air-dried tomatoes by three model reactions. Journal of Agricultural and Food Chemistry, 47, 3826-3831.

17. Lavelli, V., Kerr, W., Sri Harsha, P.S. 2013. Phytochemical stability in dried tomato pulp and peel as affected by moisture properties Journal 
of Agricultural and Food Chemistry, 61, 700707.

18. Mohseni, Sh., Ghavidel, R. Ah. (2011). Effect of pre-drying treatments on quality characteristics of dehydrated tomato slices. World Academy of Science, Engineering and Technology, 59, 2205-2215.

19. Muratore, G., Rizzo, V., Licciardello, F., Maccarone, E. (2008). Partial dehydration of cherry tomato at different temperature, and nutritional quality of the products. Food Chemistry, 111, 887-891.

20. Nagata, M., Yamashita, I. (1992). Simple method for simultaneous determination of chlorophyll and carotenoids in tomato fruit. Nippon Shokuhin Kogyo Gakkaish, 39, 925-928.

21. Nguyen, M.L., Schwartz, S.J. (1998). Lycopene stability during food processing. Proceedings of the Society for Experimental Biology and Medicine, 218, 101-105.

22. Owureku-Asare, M., Agyei-Amponsah, J., Saalia, F., Alfaro, L., Espinoza-Rodezno, L.A., Sathivel, S. (2014). Effect of pretreatment on physicochemical quality characteristics of dried tomato (Lycopersicon esculentum). African Journal of Food Science, 8, 253-259.

23. Purkayastha, M.D., Nath, A., Deka, B.C., Mahanta, C.L. (2013). Thin layer drying of tomato slices. Journal of Food Science and Technology, 50, 642-653.

24. Sacilik, K. (2007). The thin-layer modelling of tomato drying. Agriculturae Conspectus Scientificus, 72, 343-349.

25. Sacilik, K., Keskin, R., Elicin, A.K. (2006). Mathematical modelling of solar tunnel drying of thin layer organic tomato. Journal of Food Engineering, 73, 231-238.
26. Santos-Sánchez, N.F., Valadez-Blanco, R., Gómez-Gómez, M. S., Pérez-Herrera, A. SalasCoronado, R. (2012). Effect of rotating tray drying on antioxidant components, color and rehydration ratio of tomato saladette slices. LWT Food Science and Technology, 46, 298-304.

27. Shi, J., Le Maguer, M., Kakuda, Y., Liptay, A., Niekamp, F. (1999). Lycopene degradation and isomerization in tomato dehydration. Food $R e-$ search International, 32, 15-21.

28. Stahl, W., Sies, H. (1992). Uptake of lycopene and its geometrical isomers is greater from heat-processed than from unprocessed tomato juice in humans. Journal of Nutrition, 122, 2161-2166.

29. Toor, R.K., Savage G.P. (2006). Effect of semidrying on the antioxidant components of tomatoes. Food Chemistry, 94, 90-97.

30. Verlent, M.H., Rovere, P., Moldenaers, P., Van Loey, A. (2006). Rheological properties of tomato-based products after thermal and highpressure treatment. Journal of Food Science, 71, S243-S248.

31. Vinson, J.A., Hao, Y., Su, X., Zubik, L. (1998). Phenol antioxidant quantity and quality in foods: vegetables. Journal of Agricultural and Food Chemistry, 46, 3630-3634.

32. Zanoni, B., Pagliarini, E., Foschino, R. 2000. Study of the stability of dried tomato halves during shelf-life to minimise oxidative damage. Journal of the Science of Food and Agriculture, 80, 2203-2208.

33. Zdravković, J. Marković, Ž., Zdravković, M., Pavlović, R. (2012). Paradajz. Institut za povrtarstvo. Smederevska Palanka, S. Palanka, Srbija.

\title{
ОЧУВАҢЕ ВИТАМИНА Ц, ЛИКОПЕНА И УГЉЕНИХ ХИДРАТА У ПЛОДОВИМА ПАРАДАЈЗА СУШЕНИМ У ТУНЕЛСКОМ ТИПУ СУШАРА
}

Јасмина М. Здравковић ${ }^{1}$, Ненад В. Павловић ${ }^{1}$, Невенка М. Бошковић Враголовић ${ }^{2}$, Ђорђе Ж. Моравчевић ${ }^{3}$, Милан М. Шевић ${ }^{1}$

\author{
${ }^{1}$ Институт за повртарство, Карађорђева 71, Смедеревска Паланка, Србија \\ ${ }^{2}$ Универзитет у Београду, Технолошко-металуршки факултет, Карнегијева 4, Београд, Србија \\ ${ }^{3}$ Универзитет у Београду, Пољопривредни фракултет, Немањина 6, 11080 Београд-Земун,
}

Србија

Сажетак: Циљ ове студије био је проналажење оптималног начина сушења парадајза у тунелском типу сушара како би се смањили губици вредности нутритијената код сушеног производа парадајза. У овом истраживању коришћена је домаћа сорта парадајза (СП-109). Истраживање је изведено у тунелском типу сушара на три начина у пет температурних режима. Сушење је изведено у систему паралелног (варијанта 1 на $70-80{ }^{\circ} \mathrm{C}$, варијанта 2 на $90-75{ }^{\circ} \mathrm{C}$ ), супротносмерном (варијанта 1 на $55-65{ }^{\circ} \mathrm{C}$, варијанта 2 на $65-75{ }^{\circ} \mathrm{C}$ ) и комбинованог система струјања ваздуха $\left(85-55^{\circ} \mathrm{C}\right.$ и $\left.55-65^{\circ} \mathrm{C}\right)$. У овим системима сушења праћена је кинетика промена нутритивних вредности плода парадајза: садржај угљених хидрата (\%), ликопена и аскорбинске киселине (витамин Ц). Утврђени су различити утицаји температурних режима на нивоу статистичке разлике (LSD 0.05; 0.01) испитиваних система за нутритивну вредност сушеног парадајза. Паралелни систем је био статистички значајан за разлике у варијанти температуре 1 и варијанти 2. Пратећи кинетику сушења парадајза утврђено је да у свим варијантама период константног сушења траје око 3,5 часа и да је за укупно сушење најбржи паралелни проток 
топлог ваздуха и материјала. Садржај угљених хидрата у узорцима парадајза који су сушени на нижим температурама био је већи у поређењу са садржајем угљених хидрата који је утврђен у узорцима осушеним на вишим температурама сушења. На нижим температурама њихов садржај је био већи него код виших температура сушења. Значајни губици витамина Ц одређени су у свим системима сушења. Вредност ликопена у свим експерименталним условима сушења показује тенденцију благог смањења. Поредећи садржај у сувим и свежим плодовима парадајза, губитак је био од 4,94\% до 19,98\%, али не на значајном нивоу.

Кључне речи: паралелни систем, супротносмерни систем, кинетика сушења, витамин Ц, ликопен, температура

Received: 8 September 2017

Accepted: 7 December 2017 